\title{
(2) OPEN ACCESS \\ Analysis of cases managed by dermatological service in the Chinese peacekeeping level 1+ medical treatment facility in Lebanon, 2018-2019
}

\author{
Xingwang Wang, ${ }^{1}$ H Yang, ${ }^{2}$ Yuqing Wang, ${ }^{3}$ Jin Yuan, ${ }^{4}$ Qinghua $\mathrm{Yu}^{5}$
}

\begin{abstract}
'Department of Dermatology, General Hospital of Southern Theatre Command of PLA, Guangzhou, China

${ }^{2}$ Department of Dermatology, General Hospital of Southern Theatre Command of PLA, Guangzhou, China ${ }^{3}$ Department of Rehabilitation, General Hospital of Southern Theatre Command of PLA, Guangzhou, China ${ }^{4}$ Department of Pharmacy, General Hospital of Southern Theatre Command of PLA, Guangzhou, China ${ }^{5}$ Department of Emergency, General Hospital of Southern Theatre Command of PLA, Guangzhou, China
\end{abstract}

\section{Correspondence to} Professor H Yang, General Hospital of Southern Theatre Command of PLA, Guangzhou 510010, China; huilany88@ hotmail.com

Received 24 August 2019 Revised 6 November 2019 Accepted 8 November 2019

Check for updates

(c) Author(s) (or their employer(s)) 2020. Re-use permitted under CC BY-NC. No commercial re-use. See rights and permissions. Published by BMJ.

To cite: Wang $X$, Yang $H$, Wang Y, et al. BMJ Mil Health Epub ahead of print: [please include Day Month Year]. doi:10.1136/

jramc-2019-001315

\begin{abstract}
Introduction To accomplish the peacekeeping mission in Lebanon, China has deployed a level 1+ (CHN L1+) medical treatment facility (MTF) as per the new memorandum. The aim of this study was to review and analyse the skin diseases managed by Chinese dermatological service so as to gain the latest prevalence of different types of skin diseases in this mission area.

Methods All patients assessed and treated by the dermatological service of CHN L1+ MTF from January 2018 to May 2019 were included. A comparative analysis was made between this study and data published by other peacekeeping medical facilities.
\end{abstract}

Results A total of 549 patients were included (87.4\% men, with an average age of 35 years old), consisting of 399 military personnel and 150 civilians. Dermatitis and eczema $(27.1 \%)$ were the most common category of skin diseases, followed by cutaneous mycoses (13.3\%) and disorders of skin appendages (10.6\%). Among these categories, unspecified dermatitis $(9.3 \%)$, acne vulgaris $(6.6 \%)$, tinea corporis $(5.3 \%)$, folliculitis $(5.1 \%)$ and tinea pedis $(4.7 \%)$ were the top five most common reasons for dermatological consultation.

Conclusions To get a clearer understanding of the disease-type profile in this mission area was beneficial for peacekeeping doctors to make more accurate diagnosis, as well as to prepare more comprehensive medicines during the predeployment period. As dermatological service was lacking in basic medical troops, we would recommend the use of telemedicine to promote dermatological consultations when a specialist was not deployed.

\section{INTRODUCTION}

United Nations Interim Forces in Lebanon (UNIFIL) has been deployed since 1978, and around 10200 peacekeepers from 43 troop-contributing countries were conducting peacekeeping operations in this mission area. ${ }^{1}$ China has been contributing peacekeepers to UNIFIL since 2006. As per the new memorandum, since May 2016, China sent 30 military medical staff to the mission area in Lebanon every year who were based at the level $1+(\mathrm{CHN}$ $\mathrm{L} 1+$ ) medical treatment facility (MTF) in Sector East of UNIFIL. ${ }^{2}$ Besides military personnel, many civilians (including local staff, local civilians and international civilians) were also working in this mission area. The medical service of military force and civilians was supported mainly by contingents' level 1 MTFs and two level 1+ MTFs, namely UNIFIL Hospital in the headquarter of UNIFIL and CHN L1+ in Sector East. In addition to the primary

\section{Key messages}

Dermatitis and eczema were the most common category of skin diseases in this study, while unspecified dermatitis, contact dermatitis and eczematous dermatitis were the leading types of this category.

- Tinea corporis was the primary type of cutaneous mycoses while acne vulgaris was the dominant type of disorders of skin appendages.

- Dermatological service was lacking in basic military medical treatment facilities, and teledermatology might be a solution for this.

healthcare supplied by level 1 MTF, level $1+$ MTF has more modules such as primary dental care, basic laboratory facilities, forward surgical team, and so on. For the purpose of providing better service for the UNIFIL, China also sent a military dermatologist and a traditional Chinese medicine doctor to $\mathrm{CHN}$ L1+ MTF. To meet the dermatological demands of other sectors and supply humanitarian assistance to nearby locals, alternate consultations were arranged occasionally in the headquarter, nearby villages and schools. The patients who consulted in these places were also included in this study.

Historically, dermatological conditions have caused significant influence on deployed service personnel. Although skin disease has a low mortality, it contributes to a relatively large percentage of morbidity, significantly influencing the efficiency of the troops. ${ }^{3}$ For instance, during World War II, in the South Pacific theatre, skin diseases accounted for approximately $75 \%$ of all US soldiers seeking dispensary care and 20\% of hospital admissions, ${ }^{4}$ whereas in the Vietnam War, skin diseases accounted for $7.4 \%$ of all admissions and $12.2 \%$ of outpatient visits in the US troops. ${ }^{5}$ Generally, military personnel were initially screened by contingents' level $1 \mathrm{MTF}$, followed by referral to level $1+$ MTF according to the severity of diseases. Besides the military MTF, several civilian level 3 medical facilities in Tyre and Beirut that have cooperative relationships with UNIFIL could accept the referral. As only the CHN L1+ MTF was manned with a military dermatologist, physicians in contingents' level $1 \mathrm{MTF}$ were inclined to transfer patients with cutaneous disorders to our facility. As rotation periods vary from 3 months to 1 year among different contingents, the incidence of some diseases we analysed might face some bias because 
Original research

Table 1 Comparison with data published by other peacekeeping medical facilities

\begin{tabular}{|c|c|c|c|c|c|c|c|}
\hline & Lebanon & Lebanon $^{7}$ & Lebanon $^{8}$ & Sudan $^{9}$ & Sudan $^{10}$ & East Timor $^{11}$ & Cambodia $^{8}$ \\
\hline Location & Middle East & Middle East & Middle East & Africa & Africa & South-eastern Asia & South-eastern Asia \\
\hline Climate & Mediterranean & Mediterranean & Mediterranean & Savannah & Savannah & Tropical rainforest & Tropical rainforest \\
\hline Period studied & $\begin{array}{l}\text { January } 2018 \text { to May } \\
2019\end{array}$ & $\begin{array}{l}\text { April } 2007 \text { to } \\
\text { September } 2014\end{array}$ & $\begin{array}{l}\text { June } 1992 \text { to July } \\
2001\end{array}$ & $\begin{array}{l}\text { March } 2014 \text { to } \\
\text { February } 2015\end{array}$ & $\begin{array}{l}\text { January } 2010 \text { to } \\
\text { January } 2011\end{array}$ & $\begin{array}{l}\text { September } 1999 \text { to } \\
\text { February } 2000\end{array}$ & $\begin{array}{l}\text { March } 1992 \text { to } \\
\text { September } 1993\end{array}$ \\
\hline Patients, n & 549 & 1658 & 160 & 542 & 438 & 193 & 278 \\
\hline Mean age & 35 & 32 & & 30.5 & 34 & & \\
\hline Percentage of men (\%) & 87.4 & 91 & & 77.3 & 93.2 & 100 & \\
\hline \multicolumn{8}{|l|}{ Disease category (\%) } \\
\hline Dermatitis and eczema & 27.1 & 27 & 44.4 & 38.7 & $21.9^{*}$ & $16.1 \dagger$ & 8.6 \\
\hline Cutaneous mycoses & 13.8 & 15 & 16.2 & 22.5 & 10 & 23.3 & 78.5 \\
\hline Bacterial skin infection & 9.3 & 3 & 10 & & & 15.5 & 7.9 \\
\hline Viral skin disease & 7.5 & 11 & 11.9 & 3.5 & 6.8 & 17.1 & \\
\hline Acne vulgaris & 6.6 & 4 & & 10.7 & 6.6 & 1 & \\
\hline Benign neoplasm & 5.1 & 5 & 11.9 & 3.3 & & 1 & \\
\hline Urticaria & 4.6 & 3 & & 5.3 & 3.4 & 0 & \\
\hline STD & 1.8 & 2 & & 1.6 & & 0 & \\
\hline Alopecia & 2.9 & 5 & & 4 & 2.7 & 0 & \\
\hline $\begin{array}{l}\text { Disorders of } \\
\text { pigmentation }\end{array}$ & 2.7 & 1 & & $8.7 \ddagger$ & & 0 & \\
\hline
\end{tabular}

* Lichen simplex chronicus (7.1\%), asteatotic eczema (2.7\%), seborrhoeic eczema (2.5\%) and unspecified dermatitis $(9.6 \%)$ were added together.

tContact dermatitis $(9.3 \%)$, seborrhoeic dermatitis (1.6\%) and non-specific dermatitis $(5.2 \%)$ were added together.

$\mp$ Melasma $(6.2 \%)$ and dermatosis papulosa nigra $(2.5 \%)$ were added together.

STD, sexually transmitted disease.

some new rotation physicians might not choose referral as they were more experienced or due to some other reasons.

This study was aimed at investigating the latest prevalence of skin diseases among military personnel and civilians in this mission area. Therefore, the results of this study might guide other United Nations (UN) MTFs to supply better dermatological service, and the pharmacists would benefit from these data to prepare more comprehensive types of medicines in predeployment period.

\section{METHODS}

A retrospective study based on electronic hospital records was conducted for all presentations to the dermatology department at the CHN L1 + in the Sector East of UNIFIL, Lebanon, during the period between January 2018 and May 2019. The medical data were kept in the facility's internal database. Detailed data including nationality, gender, age, diagnosis, duration of diseases, registration time and treatment methods were extracted, while no private information was revealed. Military troops and military police were classified as military personnel,

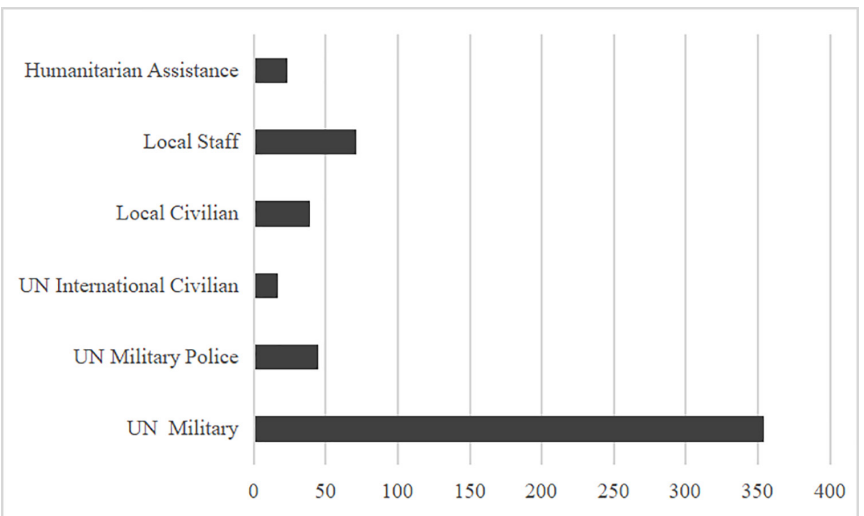

Figure 1 Identity of patients managed by dermatological service. while local civilians, international civilians, local staff and nearby locals who received humanitarian assistance were classified as civilians. Meanwhile, some major data concerning prevalence of dermatological disorders published by other peacekeeping MTFs were used for comparison. Research conducted in mission areas such as Lebanon, Sudan and East Timor were included (table 1). The category of skin diseases was determined according to the 10th version of International Classification of Diseases.

\section{RESULTS}

During the period of study, a total of 549 cases consisting of 399 military personnel and 150 civilians were referred to the dermatological service (figure 1), including $87.4 \%$ men $(n=480)$ and $12.6 \%$ women $(n=69)$, with a mean age of 35 years (range 13-48 years).

Among the 17 categories we established, dermatitis and eczema were the most common category $(n=149,27.1 \%)$, followed by cutaneous mycoses $(n=73,13.3 \%)$ and disorders of skin appendages $(n=58,10.6 \%)$. In the dermatitis and eczema category, unspecified dermatitis $(\mathrm{n}=51,9.3 \%)$, contact dermatitis $(n=36,6.6 \%)$ and eczematous dermatitis $(n=28,5.1 \%)$ were the leading types. Tinea corporis $(n=29,5.3 \%)$ was the primary type of cutaneous mycoses, while acne vulgaris $(n=36$, $6.6 \%$ ) was the dominant type of disorders of skin appendages. The top 10 dermatology disease categories were shown in table 2 and figure 2 .

In terms of specific diagnoses, unspecified dermatitis $(\mathrm{n}=51$, $9.3 \%)$, acne vulgaris $(n=36,6.6 \%)$, tinea corporis $(n=29,5.3 \%)$, folliculitis $(n=28,5.1 \%)$ and tinea pedis $(n=26,4.7 \%)$ were the top five most common reasons for dermatological consultation.

No medical evacuation caused by skin diseases was conducted during this period. Eight of 549 civilians who consulted for skin cancer were suggested to receive biopsy in level 3 hospital in Beirut, and one patient among them was diagnosed with squamous cell carcinoma. 


\begin{tabular}{lc}
\hline \multicolumn{1}{l}{ Table 2} & Frequencies of diagnoses by category \\
\hline Diagnosis & Patients, $\mathbf{n}(\%)$ \\
\hline Dermatitis and eczema & $149(27.1)$ \\
\hline Cutaneous mycoses* & $73(13.3)$ \\
\hline Disorders of skin appendages ${ }^{*}$ & $58(10.6)$ \\
\hline Bacterial skin infection $\neq$ & $51(9.3)$ \\
\hline Viral skin disease & $41(7.5)$ \\
\hline Benign neoplasm & $28(5.1)$ \\
\hline Urticaria & $28(5.1)$ \\
\hline Burn & $19(3.5)$ \\
Corns and callosities & $18(3.3)$ \\
Disorders of pigmentation & $15(2.7)$ \\
Insect bites & $12(2.2)$ \\
\hline Papulosquamous disorders & $11(2.0)$ \\
\hline Sexually transmitted disease & $10(1.8)$ \\
Radiation-related disorders & $10(1.8)$ \\
\hline Keloid and scar & $3(0.5)$ \\
\hline Others & $23(4.2)$ \\
\hline Total & $549(100)$ \\
\hline
\end{tabular}

*Cutaneous mycoses included tinea corporis $(n=29,5.3 \%)$, tinea pedis $(n=26$,

$4.7 \%)$ and tinea versicolor $(n=14,2.6 \%)$.

tAcne vulgaris $(n=36,6.6 \%)$ was the dominant type of disorders of skin appendages.

$\ddagger$ Bacterial folliculitis ( $n=28,5.1 \%$ ) was the leading type in bacterial skin infection.

Eleven patients $(n=11,2 \%)$ diagnosed with lipoma were given surgery under local anaesthesia. Only two patients required admission to hospital during this period.

\section{DISCUSSION}

Regardless of the mission type, warfare or peacekeeping troop, the incidence of dermatitis and eczema is high across multiple kinds of climates. Actually, the incidence of eczematous conditions will increase after deployment, due to reasons like psychological stress increase and climate maladjustment. During the mission period, consistent contact with chemicals, oil, uniforms, and others may trigger the eczematous condition, causing high incidence of irritant contact dermatitis and allergic contact dermatitis. $^{6}$

Dermatitis and eczema were the most common category, followed by fungal infection and acne diseases. In comparison with research published by other peacekeeping facilities, dermatitis and eczema were the leading category managed by peacekeeping facilities in Lebanon $(27.1 \%$ in $2018-2019$ period, $27 \%$ in $2007-2014$ period, $^{7} 44.4 \%$ in $1992-2001$ period, ${ }^{8}$

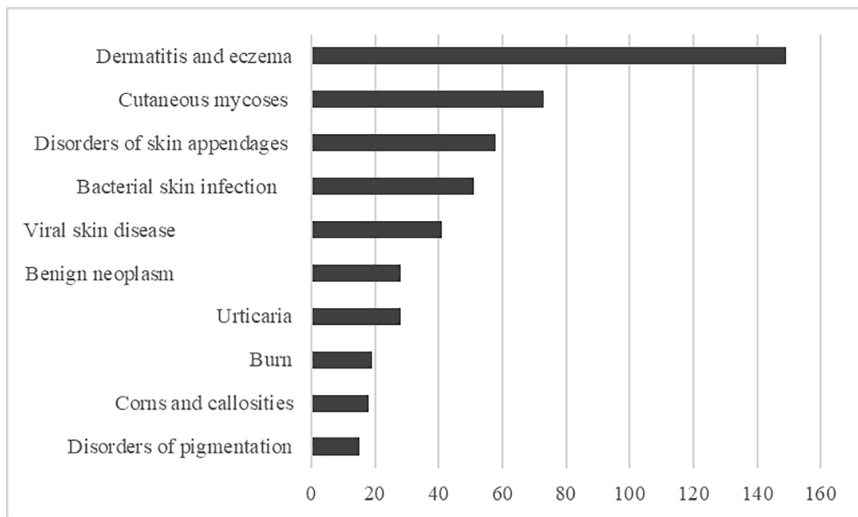

Figure 2 Top 10 categories. respectively) and in Sudan (21.9\% in 2010-2011 period, ${ }^{9}$ $38.7 \%$ in $2014-2015$ period, ${ }^{10}$ respectively), while in mission area of tropical rainforest climate, cutaneous mycoses were the leading cause $\left(78.5 \%\right.$ in Cambodia, ${ }^{8} 23.3 \%$ in East Timor).$^{11}$ Acne vulgaris is also a common disease in military mission areas, especially in young males (average age $=25$ years, $m e n=75 \%$ in our study). The incidence of acne vulgaris was relatively high in long-term study over 1 -year period $(6.6 \%, 4 \%$ in two Lebanon studies, respectively, and 10.7\%, 6.6\% in two African studies), while $1 \%$ in 6 -month East Timor study. ${ }^{11}$ While in comparison with the other two studies in Lebanon, ${ }^{78}$ incidences of viral skin disease $(7.5 \%$ vs $11 \%, 11.9 \%$, respectively) and alopecia $(2.9 \%$ vs $5 \%$ ) in the present study were remarkably lower than the former data. ${ }^{7}$

Superficial fungal infection was the second most common reason for consultation in the present study. Thereinto, tinea corporis $(5.3 \%)$ was the most prevalent complaint in this study, followed by tinea pedis (4.7\%). Hot and humid environment decreased the level of personal hygiene. Tropical environment was also to blame, as the incidence of cutaneous mycoses was extremely high in Cambodia $^{8}$ (78.5\%), a country with tropical rainforest climate. When the skin is injured or the individual's immunity decreases due to fatigue, anxiety, lack of sleep, and others, superficial non-pathogenic bacteria may become the opportunistic pathogen. A relatively high prevalence of bacterial infection was also found in the present study, with the majority being scalp folliculitis $(5.1 \%)$ in military personnel, which was supposed to be induced by long-time wearing of helmets during petrol. ${ }^{12}$ Acne vulgaris (6.6\%) was common. Patients usually complained an exacerbation of acne vulgaris after deployment. The possible reason might be the stressful psychological status. Meanwhile, acne on the face will certainly affect the confidence and mental status, as depression caused by acne is not rare. Therefore, psychological problems affecting the peacekeepers should also be highlighted. ${ }^{13} 14$

As dermatological service is not always available in lower level MTF, we highlighted the importance of teledermatology. Smart mobile terminals equipped with powerful applications such as 'Haodaifu' have spread at an amazing pace throughout China, and people lacking high-level medical care could access consultations supplied by top specialists through these telemedical service. ${ }^{15}$ US army has developed a platform named Army Knowledge Online, which is characterised by the storeand-forward method and can supply best medical service to overseas deployed soldiers. ${ }^{16} 17$ Even the common social network applications like WeChat and WhatsApp can be used for teledermatology service. A research conducted by a Korean team showed that for the diagnosis of common skin diseases, the correct rate of online diagnosis was similar to face-to-face consultation. ${ }^{18}$ Lacking dermatological service is common in UN medical facilities, and making efficient use of teledermatology can handle this problem well. For example, professional platforms like mobile applications could be developed for better medical care for military personnel and civilians working in UN mission areas.

This study had some limitations, too. First, as our facility was located in the Sector East, we mainly focused on the service for personnel in this area. Cooperative research with the UNIFIL Hospital in Sector West could be conducted in the future to get more comprehensive data. Second, the scale of the study we conducted was limited, causing existence of some bias. 


\section{CONCLUSIONS}

Pharmacists should prepare more targeted types of medicine during preparation period, so some referrals merely for prescription could decrease. Dermatological service was lacking in basic military MTFs, and teledermatology might be a solution for this. Moreover, professional telemedicine platforms could be developed for better medical care for military personnel and civilians working in UN mission areas.

Contributors XW played a major role in conducting this research. WY, YJ and YQ supplied assistance in this process.

Funding The authors have not declared a specific grant for this research from any funding agency in the public, commercial or not-for-profit sectors.

Competing interests None declared.

Patient consent for publication Not required.

Ethics approval This study is not a clinical trial, it is a retrospective analysis research, no human subjects or animal subjects were involved in this study, it does not contain any personal and/or medical information about an identifiable living individual. What's more, the Medical Section of UNIFIL encouraged us to conduct study like this. The Ethics Committee of the General Hospital of Southern Theatre Command agreed to this research. The Medical Section, Division of Mission Support of UNIFIL approved the study.

Provenance and peer review Not commissioned; internally peer reviewed.

Data availability statement Data may be obtained from a third party and are not publicly available.

Open access This is an open access article distributed in accordance with the Creative Commons Attribution Non Commercial (CC BY-NC 4.0) license, which permits others to distribute, remix, adapt, build upon this work non-commercially, and license their derivative works on different terms, provided the original work is properly cited, appropriate credit is given, any changes made indicated, and the use is non-commercial. See: http://creativecommons.org/licenses/by-nc/4.0/.

\section{REFERENCES}

1 United Nations Interim Force in Lebanon. UNIFIL Troop-Contributing countries, 2019. Available: https://unifil.unmissions.org/unifil-troop-contributing-countries [Accessed 02 May 2019].
2 China Military Online. Chinese peacekeepers participate in UNIFIL medical drill in Lebanon. Available: http://eng.chinamil.com.cn/view/2019-02/14/content_9426813. htm [Accessed 03 Oct 2019].

3 Becker LE, James WD. Military dermatology: Historical overview and principles of diagnosis. In: Zajtchuk R, ed. Textbook of military medicine. Washington, DC: Office of The Surgeon General at TMM, 1994: 1-20.

4 Vidmar DA, Harford RR, Beasley WJ, et al. The epidemiology of dermatologic and Venereologic disease in a deployed operational setting. Mil Med 1996;161:382-6.

5 Allen AM. Skin diseases In Vietnam. In: Medical department U.S. Army. Washington, DC: US Government Printing Office, 1977.

6 Gelman $A B$, Norton $S A$, Valdes-Rodriguez $R$, et al. A review of skin conditions in modern warfare and peacekeeping operations. Mil Med 2015;180:32-7.

7 Zhou Z, Liu T, Zhang Z. Skin disease in United nations peacekeepers in Lebanon. J $R$ Army Med Corps 2017:163:27-30.

8 Korzeniewski K, Olszanski R. Rating of skin problems among peacekeepers serving in the hot, dry and humid climate. International Journal of Health Science 2008:2:52-5.

9 Raza N, Agha H, Suhail M. Frequency and pattern of skin diseases among uniformed personnel at United nations level III hospital-Darfur, Sudan. Pak Armed Forces Med J 2014;64:84-7.

10 Anwar MI, Malik NA, Raja A. Skin diseases among peacekeepers at United nations and African mission in Darfur. Journal of Pakistan Association of Dermatologists 2016;26:53-7.

11 Lim DS. Dermatology in the military: an East Timor study. Int I Dermatol 2005:44:304-11.

12 Stahlman S, Williams VF, G T 0, et al. Skin and soft tissue infections, active component, us armed forces, 2013-2016. Hand 2017:2411.

13 Şenel E, Doğruer Şenel S, Salmanoğlu M. Prevalence of skin diseases in civilian and military population in a Turkish military hospital in the central black sea region. $J R$ Army Med Corps 2015;161:112-5.

14 Williams HC, Dellavalle RP, Garner S. Acne vulgaris. The Lancet 2012;379:361-72.

15 Xiong D, Zhao L. Research on Credit Evaluation of Mobile Medical APP Interactive Online Consultation Service-Take Haodaifu APP Online Payment Service as an Example[C]//Journal of Physics: Conference Series. IOP Publishing, 2017: 910

16 Vidmar DA. The history of teledermatology in the Department of defense. Dermatol Clin 1999;17:113-24.

17 Hwang J, Kakimoto C. Teledermatology in the US military: a historic foundation for current and future applications. Cutis 2018;101.

18 Shin H, Kim DH, Ryu HH, et al. Teledermatology consultation using a smartphone multimedia messaging service for common skin diseases in the Korean Army: a clinical evaluation of its diagnostic accuracy. J Telemed Telecare 2014;20:70-4. 